\title{
Seed Transmission of Pantoea stewartii in Field and Sweet Corn
}

\author{
C. C. Block, USDA-ARS North Central Regional Plant Introduction Station, J. H. Hill, Department of Plant Pa- \\ thology, and D. C. McGee, Department of Plant Pathology and Seed Science Center, Iowa State University, Ames \\ 50011
}

\begin{abstract}
Block, C. C., Hill, J. H., and McGee, D. C. 1998. Seed transmission of Pantoea stewartii in field and sweet corn. Plant Dis. 82:775-780.

Seed transmission of Pantoea stewartii was evaluated by assays of more than 76,000 plants in greenhouse and field grow-out trials. Fourteen $P$. stewartii-infected seed lots were obtained from two dent corn inbreds and two sweet corn cultivars that were inoculated with either a rifampicin and nalidixic acid-resistant strain (rif-9A) or a wild-type strain (SS104) of P. stewartii. Four additional seed lots were collected from naturally infected inbreds. Percentages of infected kernels ranged from 0.8 to $72 \%$, as determined by agar plating or by individual-kernel enzymelinked immunosorbent assay (ELISA). Plants grown from this seed were assayed by a stemprinting technique that consisted of cutting and pressing a cross-section of each stem onto agar media. Prints were examined for development of $P$. stewartii colonies after 24 and $48 \mathrm{~h}$. The transmission rate from seed produced on the inoculated plants was $0.066 \%$ ( 28 of 42,206 plants), based on all seedlings assayed. Transmission was estimated to be $0.14 \%$ from infected kernels. The transmission rate from seed produced on naturally infected plants was $0.0029 \%$ (1 of 34,924 plants), based on all seedlings, and $0.022 \%$ from infected kernels. Seed transmission occurred significantly less often $(P=0.034)$ from seed produced on naturally infected plants than from seed produced on inoculated plants, probably due to greater kernel damage caused by ear shank inoculation. The rarity of seed transmission of $P$. stewartii from heavily infected seed lots that would ordinarily be rejected due to poor germination suggests that the likelihood of seed transmission from good quality commercial seed corn is virtually nonexistent.
\end{abstract}

Additional keywords: Erwinia stewartii, seed pathology, Stewart's bacterial wilt

Despite the fact that seed transmission of Pantoea stewartii (syn. Erwinia stewartii), the cause of Stewart's disease of corn, has never been definitively proved to introduce the disease to a new region, more than 100 countries prohibit the importation of corn seed from the United States unless the shipment is certified free of $P$. stewartii.

Stewart's disease was first detected on sweet corn by F. C. Stewart in 1895 (22). Early studies provided circumstantial evidence for seed transmission of P. stewartii, with the disease developing in plants grown in the field or the greenhouse from seeds obtained from infected plants $(18,19,22)$. This work, however, was done in the absence of knowledge that the corn flea beetle, Chaetocnema pulicaria Melsh., and the toothed flea beetle, Chaetocnema denticulata Ill., were effective vectors of the pathogen $(13,14)$.

Corresponding author: Charles C. Block

E-mail: ccblock@iastate.edu

Home Economics Experiment Station, Ames, Iowa, Project No. 1018, and supported by Hatch Act and State of Iowa funds.

Accepted for publication 19 March 1998.

Publication no. D-1998-0430-02R

(C) 1998 The American Phytopathological Society
Stewart (22) suggested that the pathogen likely invaded the roots and stem by way of seed or soil, but data were ambiguous because many of the control plants were infected. Later, soil and crop residue were shown not to be inoculum sources $(8,9,14,15)$. Seed-borne infection by $P$. stewartii was established by isolation of the bacterium from the endosperm and the chalazal region of infected kernels by Ivanoff (9) and by Rand and Cash (14). Transmission of the pathogen from seeds to infected plants was demonstrated at the rate of $10.6 \%$ in the laboratory on agar slants (8) and 2 to $13 \%$ in the greenhouse (14) in the absence of other sources of inoculum. The commonly cited rate for seed transmission of $P$. stewartii is $2 \%$ from infected kernels $(5,12,17)$, but this estimate has not been verified under rigorous test conditions.

In a climate of ever-increasing quarantine regulation of pathogens in the international movement of seeds, it is necessary to ensure that regulations are justified on scientific grounds (3). This report examines the role of seed-borne $P$. stewartii in the disease cycle of Stewart's disease of maize and estimates the rate of seed-toseedling transmission from infected kernels as it relates to the risk of introducing $P$. stewartii into other countries via seed produced in the United States. Preliminary results have been reported $(1,2)$.

\section{MATERIALS AND METHODS}

Inoculum preparation. Two $P$. stewartii isolates, the wild-type strain SS104 and the rifampicin and nalidixic acid resistant strain rif-9A, previously described by Lamka et al. (11), were used for inoculum. Stock cultures were preserved in sterile $15 \%$ glycerol and stored in 1-ml cryovials at $-75^{\circ} \mathrm{C}$. Before inoculation of corn for seed harvest, bacterial strains were passed twice through the moderately resistant sweet corn cultivar Stowell's Evergreen. Inoculum was prepared by growing $P$. stewartii strains for $48 \mathrm{~h}$ on nutrient brothyeast extract agar (NBY) and suspending those cells in PBS (phosphate buffered saline, $\mathrm{pH} 7.0)$ at an absorbance $\left(A_{590 \mathrm{~nm}}\right)$ of 0.20 (approximately $2 \times 10^{8} \mathrm{CFU} / \mathrm{ml}$ ).

Seed lot production. $P$. stewartii-infected seed was obtained from pinprickinoculated or from naturally infected plants of highly susceptible dent corn inbreds (A632Ht, B14A, LH204, and a Pioneer inbred) and sweet corn cultivars (Hybrid Pride of Canada and Burnell's Golden Bantam). Table 1 lists the seed lots used in this study. Each seed lot was identified with a three-part code: the first letter representing the corn genotype, the second the bacterial strain (rif-9A, SS104, natural infection), and the number denoting successive seed lots with the same genotypebacterial strain combination (Table 1). Seed lots from the pinprick-inoculated plants are referred to as inoculated seed lots through the rest of this report.

Greenhouse-produced seed lots were generated in 1990, 1991, 1992, and 1993 from corn planted in January, grown at 24 to $26^{\circ} \mathrm{C}$ with a 13 -h day, and harvested in April. All leaves on each plant were inoculated at anthesis by the pinprick method (23). The leaf blades were inoculated near the axil on one or both sides of the midrib (Table 1). The ear shank was also pinprickinoculated in the production of several seed lots (Table 1) in an attempt to increase the percentage of severely infected kernels. Following plant maturity, ears were harvested and dried with ambient circulating air $\left(25\right.$ to $\left.27^{\circ} \mathrm{C}\right)$ to a final seed moisture content of 11 to $12 \%$. Ears were handshelled, and the seed was stored in glass jars at $5^{\circ} \mathrm{C}$ and $45 \%$ relative humidity (RH) until used for the seed transmission grow-out studies.

Field-produced seed lots were generated in 1992 and 1993. Pinprick inoculations were done in the same manner as described for the greenhouse-produced seed lots. In 
May 1992, cultivar A632Ht was planted near Ames, Iowa, in two blocks of three rows, each $90 \mathrm{~cm}$ apart and $60 \mathrm{~m}$ long. One block was inoculated at anthesis with isolate rif-9A and the second block with isolate SS104. At harvest, ears from each block were sorted into two groups based on a visual estimate of the degree of ear damage. The slightly damaged ears were designated as seed lots AR4 or AS2, corresponding to the blocks inoculated with rif9A or SS104, respectively. Similar designations of AR5 and AS3 were given to the highly damaged ears from the same blocks. In 1993, sweet corn cultivar Golden Bantam was planted on 10 June in one block of six rows $90 \mathrm{~cm}$ apart and $8 \mathrm{~m}$ long. The ears from the field-produced seed lots were dried, shelled, and stored in the manner described previously.

Naturally infected seed lots were harvested in 1992. Seed lot AN1 was harvested from a small field plot of inbred A632Ht near Ames from plants showing symptoms of systemic infection at harvest. Seed lots PN1 and PN2 were harvested from a single commercial seed production field. Seed lot PN2 was harvested from plants that were infected and prematurely killed by Stewart's disease, and PN1 was from plants that were infected but not prematurely killed. All three seed lots were processed in the manner described previously. Seed lot LN1 originated from a commercial seed production field of inbred LH204. This seed lot was harvested, conditioned, and bagged by the seed company.

Warm germination tests were conducted on most of the seed lots using the standard procedures employed at the Iowa State University Seed Science Center.
Detection of $\boldsymbol{P}$. stewartii in kernels and seedlings. Kernels from seed lots inoculated with the rif-9A isolate were assayed for P. stewartii by a kernel plating method. Five hundred kernels were assayed per seed lot, except for seed lots AR1 and HR2, with 1,000 and 1,500 kernels assayed, respectively. Kernels were surfacesterilized for $2 \mathrm{~min}$ in $0.5 \%$ sodium hypochlorite, rinsed three times in sterile deionized water, and dried on a laminar flow bench. Ten kernels were placed in each petri dish with the tips embedded in soft NBY agar (1.2\% agar). After a 48-h enrichment period at $27^{\circ} \mathrm{C}$, each kernel was removed and the tip was touched onto a plate of NBY-CRN agar. NBY-CRN, which is highly selective for the rif-9A isolate, is NBY agar amended with $50 \mathrm{mg}$ of cycloheximide, $50 \mathrm{mg}$ of rifampicin, and $25 \mathrm{mg}$ of nalidixic acid per liter (11). Twenty kernels were sampled per NBYCRN plate, and infected kernels were identified by the characteristic appearance of $P$. stewartii colonies.

Kernels from seed lots inoculated with strain SS104 or from naturally infected seed lots had no antibiotic selective markers; P. stewartii was detected in these lots by enzyme-linked immunosorbent assay (ELISA) of individual kernels (11). At least 100 kernels were sampled per seed lot. In seed lots found to contain fewer than $20 \%$ infected kernels, 100 additional kernels were assayed to obtain a more accurate estimate of the incidence of infected kernels.

The kernels were crushed in a flat-bottomed Plattner mortar (Fisher Scientific, Itasca, IL) and placed in a $12 \times 75 \mathrm{~mm}$ test tube containing $2 \mathrm{ml}$ of PBS. Samples were agitated at $100 \mathrm{rpm}$ for $1 \mathrm{~h}$. A $100-\mu \mathrm{l}$ aliquot of each sample was dispensed into a single well of a commercial P. stewartii ELISA test kit (Agdia Inc., Elkhart, IN), and the manufacturer's instructions were followed for all subsequent steps. The absorbance value for each well was measured using a Dynatech MR300 ELISA plate reader. Samples from three healthy kernels were used as negative controls on each plate, and the average absorbance of the negative controls was subtracted from each kernel absorbance. After correction for negative controls, absorbance values above 0.17 were defined as positive.

A stem-printing technique was used on greenhouse grow-outs and field grow-outs to evaluate seed transmission of $P$. stewartii. Each stem was cut off 2 to $3 \mathrm{~cm}$ above the soil line, and the base of the stem was pinched to express sap. The cut cross-section of each stem was then gently pressed onto agar media to leave a stem imprint containing plant sap on the agar. All greenhouse-grown seedlings were assayed at the two or three fully expanded leaf stage (V2 or V3). The field-grown plants were assayed at a variety of growth stages ranging from V2 to V12. The larger plants had rigid stems and were not squeezed before stem-printing. Plants grown from rif-9Ainfected seed lots were printed onto NBYCRN agar, and plants from SS104-infected or naturally infected seed lots were printed onto NBY agar. The plates were incubated at $28^{\circ} \mathrm{C}$ and visually examined for $P$. stewartii colonies after 24 and $48 \mathrm{~h}$. All colonies with a yellow color were subcultured onto fresh media, and their identity was confirmed by ELISA and basal stem injection of susceptible A632Ht corn seedlings. Two plants were injected at the twoleaf growth stage with a PBS suspension

Table 1. Seed lots produced in the field and greenhouse (GH) and percentages of Pantoea stewartii-infected kernels as determined from agar plating or by single-kernel enzyme-linked immunosorbent assay (ELISA)

\begin{tabular}{|c|c|c|c|c|c|c|c|}
\hline Seed lot code ${ }^{a}$ & $\begin{array}{c}\text { Seed production } \\
\text { year }\end{array}$ & $\begin{array}{l}\text { Seed production } \\
\text { location }\end{array}$ & Inoculation sites & $\begin{array}{c}\text { Bacterial } \\
\text { strain }\end{array}$ & $\begin{array}{c}\% \text { warm } \\
\text { germination }\end{array}$ & $\begin{array}{l}\text { Number of } \\
\text { kernels tested }\end{array}$ & $\begin{array}{c}\text { Infected } \\
\text { kernels }(\%)^{\mathbf{b}}\end{array}$ \\
\hline HR1 & 1990 & $\mathrm{GH}$ & One site/leaf & rif-9A & $\mathrm{NA}^{\mathrm{c}}$ & 500 & $14 \pm 2.5$ \\
\hline HR2 & 1991 & $\mathrm{GH}$ & One site/leaf & rif-9A & NA & 1,500 & $42 \pm 2.0$ \\
\hline HR4 & 1992 & $\mathrm{GH}$ & Two sites/leaf, shank & rif-9A & 86 & 500 & $27 \pm 3.2$ \\
\hline HS1 & 1992 & GH & Two sites/leaf, shank & SS104 & 98 & 100 & $21 \pm 6.7$ \\
\hline AR1 & 1991 & $\mathrm{GH}$ & Two sites/leaf & rif-9A & 68 & 1,000 & $72 \pm 2.3$ \\
\hline AR3 & 1992 & GH & Two sites/leaf, shank & rif-9A & 92 & 500 & $51 \pm 3.7$ \\
\hline AR4 & 1992 & Field & One site/leaf, shank & rif-9A & 90 & 500 & $37 \pm 3.6$ \\
\hline AR5 & 1992 & Field & One site/leaf, shank & rif-9A & 74 & 500 & $67 \pm 3.4$ \\
\hline AS1 & 1992 & GH & Two sites/leaf, shank & SS104 & NA & 100 & $70 \pm 7.5$ \\
\hline AS2 & 1992 & Field & One site/leaf, shank & SS104 & 81 & 100 & $48 \pm 8.2$ \\
\hline AS3 & 1992 & Field & One site/leaf, shank & SS104 & 66 & 100 & $70 \pm 7.5$ \\
\hline AN1 & 1992 & Field & Natural infection & Natural & 91 & 200 & $10 \pm 3.5$ \\
\hline BR1 & 1993 & GH & Two sites/leaf, shank & rif-9A & NA & 500 & $26 \pm 3.2$ \\
\hline GR1 & 1993 & GH & Two sites/leaf, shank & rif-9A & 87 & 500 & $40 \pm 3.6$ \\
\hline GR2 & 1993 & Field & Two sites/leaf & rif-9A & 96 & 500 & $0.8 \pm 0.6$ \\
\hline LN1 & 1992 & Field & Natural infection & Natural & 98 & 200 & $3.5 \pm 2.1$ \\
\hline PN1 & 1992 & Field & Natural infection & Natural & 99 & 200 & $9 \pm 3.3$ \\
\hline PN2 & 1992 & Field & Natural infection & Natural & 96 & 100 & $35 \pm 7.8$ \\
\hline
\end{tabular}

${ }^{a}$ Lot codes are arranged as genotype: bacterial strain: number used to distinguish similar seed lots. Genotypes: $\mathrm{H}=\mathrm{Hybrid}$ Pride of Canada sweet corn, A = inbred A632Ht, B = inbred B14A, G = Burnell's Golden Bantam open-pollinated sweet corn, L = inbred LH204, P = inbred donated by Pioneer HiBred International, Inc., Johnston, IA. Bacterial strain: R = rifampicin/nalidixic acid resistant strain rif-9A, S = wild-type strain SS104, N = from naturally infected plants via flea beetle feeding.

b Percent infected kernels $\pm 90 \%$ confidence interval.

${ }^{c}$ Not available. 
(approximately $10^{8} \mathrm{CFU} / \mathrm{ml}$ ) of each yellow isolate. The characteristic streaking and wilting symptoms associated with $P$. stewartii infection typically appeared after 2 days. Symptomless plants were reexamined after 7 days. Representative colonies of every commonly occurring non-yellow bacteria were subcultured from each growout test and tested by ELISA or basal stem injection to ensure that they were not strains of $P$. stewartii.

Sensitivity of the stem-printing assay was compared on NBY and NBY-CRN media. Two hundred greenhouse-grown plants of inbred A632Ht were inoculated at the two-leaf growth stage with strain rif9A by basal stem injection. After 8 days, each plant was cut off 2 to $3 \mathrm{~cm}$ above the injection point and stem-printed onto both NBY and NBY-CRN agar. Seedlings were identified by a grid drawn on each plate. The NBY-CRN plates yielded only pure cultures of $P$. stewartii; therefore, infected seedlings were identified by the characteristic appearance of $P$. stewartii colonies. The NBY plates were visually compared to the NBY-CRN plates for evidence of $P$. stewartii growth at the same plate locations. All suspected P. stewartii colonies were confirmed by ELISA. The test was repeated with 200 seedlings from seed lot PN1.

Grow-out tests for seed transmission. The field grow-out tests for seed transmission of $P$. stewartii were planted near Ames. The number of plants evaluated varied because of differences in the quantities of seed available and because multiple planting dates were used to provide different environments (Table 2). The first experiment, planted on 2 July 1990, comprised a set of 41 rows of corn seed, each row originating from a single ear of seed lot HR1. After 30 days, 10 plants were assayed per row.

In 1991, seed lots AR1 and HR2 were planted on 24 May and again on 6 June in rows $18 \mathrm{~m}$ long and $45 \mathrm{~cm}$ apart. The plantings were arranged as split plots with half of the replications covered with horticultural row-cover netting to exclude corn flea beetles. Wire hoops were placed at 2.5-m intervals to support the fabric, and the fabric edges were covered with soil. Noncovered plots were sprayed weekly with carbaryl insecticide. Plots were inspected every 2 days for plants showing wilting, yellowing, graying, or browning of the leaf tissue. Symptomatic plants were dug out and assayed by stem-printing on NBY-CRN agar.

In 1992, seed lots AR3, HR4, and AS1 were planted on 8 June and again on 18 June using the same plot dimensions as in 1991. The plots were arranged in a completely randomized design, and all plots were covered by netting. Plants were dug out at the V3 to V4 growth stage, sprayed with water to remove soil, and assayed for the presence of $P$. stewartii by stem-printing. Seed lots AR3 and HR4 were printed on NBY-CRN agar, and AS1 was printed on NBY agar. The prints from seed lot AS1 were excessively contaminated by bacteria and fungi and could not be assessed for $P$. stewartii. Instead, stem sections from 470 plants were assayed for $P$. stewartii by ELISA.

In 1993, seed lots AR4, AR5, BR1, and GR1 were planted on 11 June and again on 21 July in two-row plots $9 \mathrm{~m}$ long and $1 \mathrm{~m}$ apart. The plots were arranged in a completely randomized design, and all plots were covered by netting. Plants from one row of each plot were assayed by stem-printing when the majority of plants reached the V6 growth stage; the second row was tested at the V12 growth stage.

Seed lots in greenhouse grow-out trials were planted in flats containing a pasteurized soil mix. Greenhouse temperature was maintained at 24 to $26^{\circ} \mathrm{C}$ during the day and $21^{\circ} \mathrm{C}$ at night. The numbers of seeds tested and the test dates varied (Tables 3 and 4). All of the SS104-infected and naturally infected seed lots were grown only in the greenhouse, except for one field test of seed lot AS1 (Table 1). Field-grown plants were difficult to clean sufficiently to prevent bacterial and fungal contamination of the NBY agar.

Estimation of seed transmission rates. The seed transmission rates were adjusted to reflect the proportion of plants estimated to have actually emerged from infected kernels, allowing better comparisons across seed lots. These values, designated as the number of potential PS-positive plants, were obtained by multiplying the total number of plants tested from a seed lot by the average percentage of infected kernels in the seed lot. The positive instances of seed transmission were called the number of actual PS-positive plants. Seed transmission rates were calculated by dividing the number of actual PS-positive plants by the number of potential PS-positive plants. To obtain a measure of confidence in the overall seed transmission estimates, low and high seed transmission rates were calculated for the inoculated seed lots (all field and greenhouse data combined) and for the naturally infected seed lots (all greenhouse data combined). Low and high rates were calculated by using the lower and upper confidence limits for the percentage of infected kernels in each seed lot (Table 1) and adjusting the

Table 2. Seed-to-seedling transmission of Pantoea stewartii (PS) from seed from inoculated plants in field grow-out tests

\begin{tabular}{|c|c|c|c|c|c|c|c|c|c|c|}
\hline \multirow[b]{2}{*}{$\begin{array}{l}\text { Seed lot } \\
\text { code }\end{array}$} & \multirow[b]{2}{*}{$\begin{array}{c}\text { Date } \\
\text { planted }\end{array}$} & \multirow[b]{2}{*}{$\begin{array}{l}\text { No. of } \\
\text { plots }\end{array}$} & \multirow[b]{2}{*}{$\begin{array}{c}\text { Seeds/ } \\
\text { plot }\end{array}$} & \multirow{2}{*}{$\begin{array}{l}\text { Growth } \\
\text { stage at } \\
\text { testing }\end{array}$} & \multirow[b]{2}{*}{$\begin{array}{c}\text { Percent } \\
\text { emergence }\end{array}$} & \multicolumn{3}{|c|}{ No. of plants evaluated } & \multirow{2}{*}{$\begin{array}{c}\text { Seed } \\
\text { transmission } \\
\text { rate for } \text { PS }^{\mathbf{c}}\end{array}$} & \multirow{2}{*}{$\begin{array}{c}\text { Maximum } \\
\text { estimated rate } \\
(95 \% \mathrm{CL})^{\mathrm{d}}\end{array}$} \\
\hline & & & & & & Total & $\begin{array}{c}\text { Potential } \\
\text { PS-positive }^{\text {b }}\end{array}$ & $\begin{array}{c}\text { Actual } \\
\text { PS-positive }\end{array}$ & & \\
\hline HR1 & $7 / 2 / 90$ & 41 & $20-40$ & V4-V5 & $\ldots$ & 410 & 57 & 0 & 0.00000 & 0.05263 \\
\hline \multirow{2}{*}{ HR2 } & $5 / 24 / 91$ & 8 & 200 & V2-V3 & 88.7 & 1,419 & 596 & 2 & 0.00173 & 0.00545 \\
\hline & 6/6/91 & 8 & 200 & V2-V3 & 83.2 & 1,332 & 559 & 0 & & \\
\hline \multirow[t]{2}{*}{ HR4 } & $6 / 8 / 92$ & 8 & 200 & V3-V4 & 80.3 & 860 & 232 & 0 & 0.00000 & 0.00804 \\
\hline & $6 / 18 / 92$ & 7 & 200 & V3-V4 & 83.3 & 523 & 141 & 0 & & \\
\hline \multirow[t]{2}{*}{ AR1 } & $5 / 24 / 91$ & 8 & 200 & V2-V3 & 47.9 & 767 & 552 & 3 & 0.00744 & 0.01397 \\
\hline & $6 / 6 / 91$ & 6 & 200 & V2-V3 & 45.0 & 540 & 389 & 4 & & \\
\hline AS1 & $6 / 8 / 92$ & 5 & 200 & V3-V4 & 69.0 & 470 & 329 & 0 & 0.00000 & 0.00912 \\
\hline \multirow[t]{2}{*}{ AR3 } & $6 / 8 / 92$ & 9 & 200 & V3-V4 & 73.2 & 940 & 479 & 0 & 0.00000 & 0.00401 \\
\hline & $6 / 18 / 92$ & 9 & 200 & V3-V4 & 75.7 & 527 & 269 & & & \\
\hline \multirow[t]{2}{*}{ AR4 } & $6 / 11 / 93$ & 12 & 400 & V6,V12 & 62.2 & 2,984 & 1,104 & 0 & 0.00127 & 0.00328 \\
\hline & $7 / 21 / 93$ & 10 & 400 & V6,V12 & 84.8 & 3,394 & 1,256 & 3 & & \\
\hline \multirow[t]{2}{*}{ AR5 } & $6 / 11 / 93$ & 10 & 400 & V6,V12 & 32.1 & 1,284 & 860 & 2 & 0.00122 & 0.00279 \\
\hline & $7 / 21 / 93$ & 15 & 400 & V6,V12 & 60.2 & 3,615 & 2,422 & 2 & & \\
\hline BR1 & $6 / 11 / 93$ & 5 & 400 & V6,V12 & 43.3 & 866 & 225 & 0 & 0.00000 & 0.01333 \\
\hline \multirow{2}{*}{ GR1 } & $6 / 11 / 93$ & 9 & 400 & V6,V12 & 61.6 & 2,219 & 888 & 0 & 0.00000 & 0.00165 \\
\hline & $7 / 21 / 93$ & 7 & 400 & V6,V12 & 82.8 & 2,317 & 927 & 0 & & \\
\hline Overall & & & & & & 24,467 & 11,285 & 16 & 0.00142 & 0.00215 \\
\hline
\end{tabular}

\footnotetext{
${ }^{a}$ Growth stage determined by number of visible leaf collars. V6, V12 were two-row plots with each row tested at a different stage.

${ }^{b}$ Total number of plants evaluated multiplied by the percentage of infected kernels (from Table 1).

c Total number of actual PS-positive plants/total number of potential PS-positive plants for the seed lot.

${ }^{\mathrm{d}}$ Upper one-sided confidence limit.
} 
numbers of potential PS-positive plants for each seed lot accordingly.

A one-sided $95 \%$ upper confidence limit was calculated for the seed transmission rate from each seed lot by the method described by Couey and Chew for quarantine data (4). The upper confidence limit provided a means for assessing the reliability of the seed transmission estimates when a limited number of plants were tested and also when no instances of seed transmission were detected.

\section{RESULTS}

Sensitivity of stem-printing assay. Recovery of isolate rif-9A from inoculated plants was $98.5 \%$ efficient (394 of 400 plants) on NBY-CRN agar, compared with $52 \%$ recovery (208 of 400 plants) from the same plants when printed on NBY agar. On NBY-CRN, every positive print yielded a pure culture of $P$. stewartii. On NBY, $P$. stewartii was frequently found in mixed cultures with other bacteria. P. stewartii was sometimes obscured by the fastgrowing Pantoea agglomerans, as it was not visible on NBY agar when present at the same plate location on NBY-CRN agar.

Transmission of $P$. stewartii from seed of inoculated plants. Seed transmission was detected from 4 of 10 inoculated seed lots tested in field grow-out trials from 1990 to 1993 (Table 2) and from 4 of 10 inoculated seed lots tested in greenhouse grow-out trials from 1990 to 1994 (Table $3)$. All of the seed lots with positive instances of seed transmission (HR2, AS2, AS3, AR1, AR4, and AR5) contained more than $35 \% \quad P$. stewartii-infected kernels. Seed transmission was not demonstrated from three seed lots (GR1,
$\mathrm{AR} 3$, and AS1) that also contained more than $35 \%$ P. stewartii-infected kernels.

A total of 24,467 plants were tested in the field, of which 11,285 were estimated to be potential PS-positive plants (Table 2) based on the percentage of infected seed (Table 1). Sixteen instances of seed transmission were detected, resulting in an adjusted seed transmission rate of 0.00142 (16 of 11,285). The $95 \%$ upper confidence limit was $0.00215(0.22 \%)$, indicating that the maximum transmission rate would probably be about two instances of seed transmission from 1,000 infected kernels.

A total of 17,838 plants were tested in the greenhouse, of which 8,450 were estimated to be potential PS-positive plants (Table 3) based on the percentage of infected seed (Table 1). Twelve instances of seed transmission were detected, resulting in an adjusted seed transmission rate of

Table 3. Seed-to-seedling transmission of Pantoea stewartii (PS) from seed harvested from inoculated plants as determined in greenhouse grow-out tests

\begin{tabular}{|c|c|c|c|c|c|c|c|c|c|c|}
\hline \multirow[b]{2}{*}{$\begin{array}{l}\text { Seed lot } \\
\text { code }\end{array}$} & \multirow[b]{2}{*}{$\begin{array}{c}\text { Date } \\
\text { planted }\end{array}$} & \multirow[b]{2}{*}{$\begin{array}{l}\text { No. of } \\
\text { flats }\end{array}$} & \multirow[b]{2}{*}{$\begin{array}{c}\text { Seeds/ } \\
\text { flat }\end{array}$} & \multirow{2}{*}{$\begin{array}{c}\text { Growth } \\
\text { stage at } \\
\text { testing }\end{array}$} & \multirow[b]{2}{*}{$\begin{array}{c}\text { Percent } \\
\text { emergence }\end{array}$} & \multicolumn{3}{|c|}{ No. of plants evaluated } & \multirow{2}{*}{$\begin{array}{c}\text { Seed } \\
\text { transmission } \\
\text { rate for } \text { PS }^{\mathbf{b}}\end{array}$} & \multirow{2}{*}{$\begin{array}{c}\text { Maximum } \\
\text { estimated rate } \\
(95 \% \mathrm{CL})^{\mathrm{c}}\end{array}$} \\
\hline & & & & & & Total & $\begin{array}{c}\text { Potential } \\
\text { PS-positive }\end{array}$ & $\begin{array}{c}\text { Actual } \\
\text { PS-positive }\end{array}$ & & \\
\hline HR1 & 4/7/90 & 8 & 60 & V2-V3 & 63.5 & 305 & 43 & 0 & 0.00000 & 0.06977 \\
\hline HS1 & $7 / 6 / 92$ & 2 & 125 & V2-V3 & 98.8 & 247 & 52 & 0 & 0.00000 & 0.05769 \\
\hline AS1 & $7 / 6 / 92$ & 4 & 125 & V2-V3 & 78.2 & 391 & 274 & 0 & 0.00000 & 0.01095 \\
\hline \multirow[t]{3}{*}{ AS2 } & $11 / 11 / 92$ & 20 & 125 & V2-V3 & 88.5 & 2,213 & 1,062 & 0 & 0.00044 & 0.00207 \\
\hline & $3 / 4 / 93$ & 8 & 250 & V2-V3 & 85.7 & 1,714 & 823 & 1 & & \\
\hline & $10 / 20 / 93$ & 4 & 250 & V2-V3 & 83.7 & 837 & 402 & 0 & & \\
\hline \multirow[t]{4}{*}{ AS3 } & $11 / 11 / 92$ & 20 & 125 & V2-V3 & 60.9 & 1,522 & 1,065 & 1 & 0.00069 & 0.00217 \\
\hline & 3/4/93 & 8 & 250 & V2-V3 & 54.8 & 1,096 & 767 & 0 & & \\
\hline & $3 / 22 / 93$ & 6 & 250 & V2-V3 & 44.1 & 661 & 463 & 0 & & \\
\hline & $10 / 20 / 93$ & 6 & 250 & V2-V3 & 57.7 & 865 & 606 & 1 & & \\
\hline \multirow[t]{2}{*}{ AR4 } & $12 / 21 / 92$ & 8 & 250 & V2-V3 & 94.1 & 1,882 & 696 & 3 & 0.00375 & 0.00858 \\
\hline & $10 / 20 / 93$ & 4 & 275 & V2-V3 & 90.9 & 1,000 & 370 & 1 & & \\
\hline \multirow[t]{2}{*}{ AR5 } & $12 / 21 / 92$ & 8 & 250 & V2-V3 & 68.0 & 1,359 & 911 & 0 & 0.00352 & 0.00740 \\
\hline & $10 / 20 / 93$ & 4 & 275 & V2-V3 & 69.1 & 760 & 509 & 5 & & \\
\hline BR1 & $5 / 24 / 93$ & 2 & 250 & V2-V3 & 94.4 & 472 & 123 & 0 & 0.00000 & 0.02439 \\
\hline GR1 & $5 / 6 / 93$ & 3 & 250 & V2-V3 & 89.6 & 672 & 269 & 0 & 0.00000 & 0.01115 \\
\hline GR2 & 2/18/94 & 8 & 250 & V2-V3 & 92.1 & 1,842 & 15 & 0 & 0.00000 & 0.20000 \\
\hline Overall & & & & & & 17,838 & 8,450 & 12 & 0.00142 & 0.00230 \\
\hline
\end{tabular}

a Total number of plants evaluated multiplied by the percentage of infected kernels (from Table 1).

${ }^{\mathrm{b}}$ Total number of actual PS-positive plants/total number of potential PS-positive plants for the seed lot.

${ }^{c}$ Upper one-sided confidence limit.

Table 4. Seed-to-seedling transmission of Pantoea stewartii (PS) from seed harvested from naturally infected field-grown plants as determined in greenhouse grow-out tests

\begin{tabular}{|c|c|c|c|c|c|c|c|c|c|c|}
\hline \multirow[b]{2}{*}{$\begin{array}{l}\text { Seed lot } \\
\text { code }\end{array}$} & \multirow[b]{2}{*}{$\begin{array}{c}\text { Date } \\
\text { planted }\end{array}$} & \multirow[b]{2}{*}{$\begin{array}{l}\text { No. of } \\
\text { flats }\end{array}$} & \multirow[b]{2}{*}{$\begin{array}{l}\text { Seeds/ } \\
\text { flat }\end{array}$} & \multirow{2}{*}{$\begin{array}{c}\text { Growth } \\
\text { stage at } \\
\text { testing }\end{array}$} & \multirow[b]{2}{*}{$\begin{array}{c}\text { Percent } \\
\text { emergence }\end{array}$} & \multicolumn{3}{|c|}{ No. of plants evaluated } & \multirow{2}{*}{$\begin{array}{c}\text { Seed } \\
\text { transmission } \\
\text { rate for } \text { PS }^{\mathbf{b}}\end{array}$} & \multirow{2}{*}{$\begin{array}{c}\text { Maximum } \\
\text { estimated rate } \\
(95 \% \mathrm{CL})^{\mathbf{c}}\end{array}$} \\
\hline & & & & & & Total & $\begin{array}{c}\text { Potential } \\
\text { PS-positive }^{\mathrm{a}}\end{array}$ & $\begin{array}{c}\text { Actual } \\
\text { PS-positive }\end{array}$ & & \\
\hline \multirow[t]{3}{*}{ AN1 } & $11 / 23 / 92$ & 10 & 250 & V2-V3 & 95.4 & 2,386 & 239 & 0 & 0.00000 & 0.00159 \\
\hline & 2/8/94 & 8 & 275 & V2-V3 & $\mathrm{NA}^{\mathrm{d}}$ & 2,000 & 200 & 0 & & \\
\hline & $12 / 4 / 95$ & 64 & 250 & V2-V3 & 90.4 & 14,473 & 1,447 & 0 & & \\
\hline \multirow[t]{4}{*}{ PN1 } & $2 / 19 / 93$ & 8 & 250 & $\mathrm{~V} 2-\mathrm{V} 3$ & 93.0 & 1,860 & 167 & 1 & 0.00137 & 0.00648 \\
\hline & 9/19/93 & 5 & 250 & $\mathrm{~V} 2-\mathrm{V} 3$ & NA & 1,000 & 90 & 0 & & \\
\hline & $1 / 10 / 94$ & 9 & 275 & V2-V3 & NA & 2,000 & 180 & 0 & & \\
\hline & $12 / 28 / 95$ & 14 & 250 & V2-V3 & 93.3 & 3,267 & 294 & 0 & & \\
\hline \multirow[t]{3}{*}{ PN2 } & 2/16/93 & 10 & 250 & V2-V3 & 91.8 & 2,296 & 804 & 0 & 0.00000 & 0.00162 \\
\hline & $9 / 19 / 93$ & 5 & 250 & V2-V3 & NA & 1,000 & 350 & 0 & & \\
\hline & 1/10/94 & 9 & 275 & V2-V3 & NA & 2,000 & 700 & 0 & & \\
\hline \multirow[t]{2}{*}{ LN1 } & $10 / 26 / 92$ & 4 & 250 & $\mathrm{~V} 2-\mathrm{V} 3$ & 78.1 & 781 & 27 & 0 & 0.00000 & 0.03261 \\
\hline & 2/8/94 & 8 & 275 & V2-V3 & 84.5 & 1,861 & 65 & 0 & & \\
\hline Overall & & & & & & 34,924 & 4,563 & 1 & 0.00022 & 0.00104 \\
\hline
\end{tabular}

a Total number of plants evaluated multiplied by the percentage of infected kernels (from Table 1).

${ }^{b}$ Total number of actual PS-positive plants/total number of potential PS-positive plants for the seed lot.

c Upper one-sided confidence limit.

${ }^{\mathrm{d}}$ Not available; not all plants were tested and emergence was not calculated. 
$0.00142(12$ of 8,450$)$, which was identical to the field rate of 0.00142 . The $95 \%$ upper confidence limit was $0.00230(0.23 \%)$. The adjusted seed transmission rate from all of the inoculated seed lots (combined field and greenhouse data) was 0.00142 , with low and high rate estimates of 0.00130 and 0.00156 , respectively.

Six of the 10 seed lots in either trial (field or greenhouse) were tested in both locations during the same season-HR1, AS1, AR4, AR5, BR1, and GR1—with the same results. That is, seed transmission was detected from AR4 and AR5 (37\% and $67 \%$ infected seed), but not from HR1, AS1, BR1, and GR1. The average seed transmission rate for seed lots AR4 and AR5 under field conditions was 0.00124 (combined data), compared with 0.00362 in the greenhouse. To test whether the greenhouse was more favorable to seed transmission than the field, the two binomial proportions, namely 7 of 5,642 potential positive plants in the field and 9 of 2,486 potential positive plants in the greenhouse, were compared by a chisquare test of independence for a $2 \times 2$ contingency table with one degree of freedom (20). The chi-square value of 4.97 corresponded to a $P$ value of 0.026 and provided strong evidence that the two proportions were truly different. The greenhouse environment was probably more conducive to seed transmission because of higher percentage germination of poor vigor seeds (Tables 2 and 3 ).

The rate of seed transmission from the rif-9A seed lots tested in the greenhouse (9 of 2,936 plants) was significantly higher ( $P$ $=0.0034)$, as determined by a chi-square test, than that from the SS104-infected seed lots ( 3 of 5,514 plants). Doubling the number of positive instances of seed transmission in the SS104 seed lots, to adjust for the lower stem-printing detection sensitivity on NBY, resulted in a $P$ value of 0.040 .

Transmission of $P$. stewartii from naturally infected seed. Only one instance of seed-to-seedling transmission was found among the 34,924 plants assayed from the naturally infected seed lots. The adjusted seed transmission rate was 0.00022 ( 1 of 4,563 potential PS-positive plants), with a $95 \%$ upper confidence limit of 0.00104 (Table 4). The low and high rate estimates were 0.00017 and 0.00032 , respectively.

The single PS-positive plant came from the first 2,000 plants tested of seed lot PN1 ( $9 \%$ infected kernels). Assays of approximately 6,000 additional plants from the same seed lot were negative. Seed lot PN2 was the same genotype, containing a much higher percentage of infected kernels $(35 \%)$ and more visibly damaged kernels, but no seed transmission was detected from 5,296 plants tested (Table 4). Seed lot AN1 was quite similar to PN1, in that both were dent corn inbreds that contained about $10 \%$ infected kernels, but no seed transmission was detected from almost 19,000 plants tested.

Comparison of seed transmission from inoculated and naturally infected seed lots. The average seed transmission rate from the inoculated seed lots (combined field and greenhouse data) was 0.00142 (28 of 19,735 potential PS-positive plants), which was 6.5 times higher than the average rate of 0.00022 from the naturally infected seed lots (1 of 4,563 potential PS-positive plants). The two proportions, namely $1 / 4,563$ and $28 / 19,735$, were compared by a chi-square test (20) to determine if they were significantly different. The chi-square statistic of 4.47 corresponded to a $P$ value of 0.034 and provided strong evidence that seed transmission occurred at a significantly lower frequency from the naturally infected seed lots. Because stem-printing onto NBY agar was about $50 \%$ less sensitive than printing on NBY-CRN agar, the transmission rate for the naturally infected seed was multiplied by two and reanalyzed by a chi-square test. The resulting chi-square statistic of 2.90 corresponded to a $P$ value of 0.088 , still reasonably good evidence that there was a real difference between the two rates. If seed transmission from the naturally infected seed lots had occurred at a rate of $0.14 \%$, about six to seven cases of seed transmission would have been expected.

\section{DISCUSSION}

This study produced seed transmission rates that were considerably lower than the $2 \%$ figure prevalent in the literature $(5,12,17)$. Many of the early seed transmission studies were field grow-out tests whose results were confounded by disease introduced by the corn flea beetle, and seed transmission could not be confirmed. Therefore, the $2 \%$ figure seems to be based on results of small greenhouse tests by Rand and Cash $(13,14)$, who reported one wilted plant from 54 seed $(2 \%)$ in one test and 3 wilted plants from 23 seed $(13 \%)$ in a second test. Rand and Cash (14) also reported about $2 \%$ wilted plants from a third greenhouse planting of 2 quarts of badly diseased seed, but no cases of wilt among hundreds of plants grown from open-market seed in the same greenhouse. It is not clear if P. stewartii was confirmed by isolation as the actual cause of the wilted seedlings in these studies $(13,14)$.

As Khan et al. (10) suggested, differences in the seed transmission rates reported in the early literature and those found in recent observations may be due, in part, to improved levels of Stewart's disease resistance in modern cultivars. The genotypes used in the study were all highly susceptible, however, and several of the seed lots should have resembled the poor quality seed samples described in the early literature $(8,9,14,19)$. Therefore, alternative conclusions should be considered as to why the transmission rates were so much lower. Ear rotting fungi are a potential cause of seedling wilts that may have been overlooked in the early 1900s. Fungi such as Diplodia zeae, Fusarium moniliforme, Penicillium oxalicum, and Gibberella zeae were reported as causing significant ear rot and seedling wilt problems in the 1920 s and 1930s $(16,21,24)$, and they were, in all likelihood, present in the early 1900s as well. We regularly found wilting seedlings, from which $P$. stewartii could not be detected by plating or ELISA, but which were infected by $P$. oxalicum or F. moniliforme.

The seed lots used in this study generally contained very high percentages of infected kernels. The advantage in using such seed lots was to greatly increase the number of infected kernels planted and therefore increase the probability of detecting seed transmission. The main disadvantages are that these seed lots were not representative of the seed quality found in commercial seed production and that internationally accepted quality standards for germination alone would likely eliminate them as sources for seed corn. Our experience in testing naturally infected seed lots has been that seed lots containing more than 5\% P. stewartii-infected kernels (e.g., AN1, PN1, and PN2) are seldom found, and then only from systemically infected plants. If the seed lots with $35 \%$ or higher incidence of infected kernels were eliminated from this study, 28 positive plants would have been eliminated, leaving the single instance of seed transmission from seed lot PN1. We conducted the field grow-out trials under a variety of conditions (e.g., soil temperature, moisture, planting time, years) to expose the infected seeds to several different environments. There is reassurance in noting that, despite our efforts to favor the pathogen, seed transmission of $P$. stewartii was quite rare overall and did not occur from 11 of 18 seed lots.

We expected the sweet corn cultivars, Hybrid Pride of Canada and Golden Bantam, to display higher rates of seed transmission than the dent corn cultivars because of the large conformational changes that the sweet corn kernels undergo during imbibition and germination. Cracks in the germinating seeds plus sugary exudates could favor bacterial entry and growth. Only two instances of seed transmission were detected from 3,779 potential PSpositive sweet corn plants tested $(0.053 \%)$. Thus, sweet corn did not seem to be more prone to seed transmission than dent corn. Using a corn genotype with the shrunken kernel gene (sh2) might have been more conducive to demonstrating seed transmission in sweet corn.

The data in this study can be used to estimate the risk of seed transmission from a given seed lot if the percentage of infected kernels is known. If a seed lot contained $1 \%$ infected kernels and one assumed a 
seed transmission rate of $0.14 \%$, as observed from the inoculated seed lots, the expected percentage of $P$. stewartii-infected seedlings would be $0.0014 \%$, or 14 per $1,000,000$ plants. At 62,500 plants per hectare $(25,000 /$ acre $)$, there would be an average of slightly less than one case of seed transmission per hectare. If the seed transmission rate was $0.022 \%$, as observed from the naturally infected seed lots, the expected percentage of $P$. stewartii-infected seedlings would be $0.00022 \%$, or about two cases per $1,000,000$ plants. At 62,500 plants per hectare, there would be an average of one case of seed transmission per 8 hectares (20 acres).

An additional factor that reduces the risk of spreading Stewart's disease through seed is the dependence of the pathogen on an insect vector. The pathogen has not been shown to spread effectively from plant to plant, except by flea beetle vectors (12). In the absence of an insect capable of acquiring and transmitting the pathogen, the bacterium would be more or less restricted to the original plant. Plant-to-plant spread was not specifically addressed in this study, but no spread was observed from inoculated rows into adjacent noninoculated rows in the absence of flea beetles, in either 1990 or 1991. Elliot and Poos (7) collected and cultured bacteria from 28,769 insects representing 94 species and concluded that, although several insect species could pick up and carry the bacterium in a transient manner when confined to infected corn, only $C$. pulicaria and $C$. denticulata were important vectors under natural field conditions. Elliott and Poos $(6,7)$ also concluded that $C$. pulicaria was the only species of importance for long-term survival of the bacterium over the winter.

From a practical standpoint, the remaining challenge is to assess what risk, if any, is posed by good quality seed with a low incidence of infected kernels. Our results are consistent with those of Khan et al. (10), who found no seed transmission among 75,000 seedlings grown from seed that had relatively low levels of $P$. stewartii-infected kernels. Further grow-out studies in other locations or in countries affected by the regulations may be warranted to see if transmission rates remain consistent with those in our trials, but it seems clear that the threat of seed transmission of $P$. stewartii has been exaggerated and that the risk of seed transmission from good quality seed is virtually nonexistent. The present zero-tolerance phytosanitary regulations are based on limited and seemingly inadequate scientific information. Modifying the field inspection aspect of the present quarantine system to account for systemic and nonsystemic plant infection should be considered with the overall objective of ensuring that phytosanitary regulations are scientifically justified.

\section{ACKNOWLEDGMENTS}

This research was supported by the USDA-ARS North Central Regional Plant Introduction Station. We thank G. Munkvold for his critical review of the manuscript.

\section{LITERATURE CITED}

1. Block, C. C., McGee, D. C., and Hill, J. H. 1992. Seed transmission of Erwinia stewartii in corn under field conditions. (Abstr.) Phytopathology 82:1154.

2. Block, C. C., McGee, D. C., and Hill, J. H. 1994. Assessing risk of seed transmission of Erwinia stewartii in maize. (Abstr.) Phytopathology 84:1153.

3. Condon, M. 1997. Implications to international trading of seeds. Pages 17-30 in: Plant Pathogens and the Worldwide Movement of Seeds. D. C. McGee, ed. American Phytopathological Society, St. Paul, MN.

4. Couey, H. M., and Chew, V. 1986. Confidence limits and sample size in quarantine research. J. Econ. Ent. 79:887-890.

5. Elliott, C. 1941. Bacterial wilt of corn. USDA Farmer's Bull. 1878.

6. Elliott, C., and Poos, F. W. 1934. Overwintering of Aplanobacter stewartii. Science 80:289-290.

7. Elliott, C., and Poos, F. W. 1940. Seasonal development, insect vectors, and host range of bacterial wilt of sweet corn. J. Agric. Res. 60:645-686.
8. Frutchey, C. W. 1936. A study of Stewart's disease of sweet corn caused by Phytomonas stewarti. Mich. Agric. Exp. Stn. Tech. Bull. 152.

9. Ivanoff, S. S. 1933. Stewart's wilt disease of corn, with emphasis on the life history of Phytomonas stewartii in relation to pathogenesis. J. Agric. Res. 47:749-770.

10. Khan, A., Ries, S. M., and Pataky, J. K. 1996. Transmission of Erwinia stewartii through seed of resistant and susceptible field and sweet corn. Plant Dis. 80:398-403.

11. Lamka, G. L., Hill, J. H., McGee, D. C., and Braun, E. J. 1991. Development of an immunosorbent assay for seedborne Erwinia stewartii in corn seeds. Phytopathology 81:839-846.

12. Pepper, E. H. 1967. Stewart's bacterial wilt of corn. American Phytopathological Society Monogr. No. 4.

13. Rand, F. V., and Cash, L. C. 1924. Further evidence of insect dissemination of bacterial wilt of corn. Science 59:67-69.

14. Rand, F. V., and Cash, L. C. 1933. Bacterial wilt of corn. USDA Tech. Bull. 362.

15. Reddy, C. H. 1921. Experiments with Stewart's disease on dent, flint, and sweet corn. (Abstr.) Phytopathology 11:31.

16. Reddy, C. S., Holbert, J. R., and Erwin, A. T. 1926. Seed treatments for sweet-corn diseases. J. Agric. Res. 33:769-779.

17. Robert, A. L. 1955. Bacterial wilt and Stewart's leaf blight of corn. USDA Farmer's Bull. 2092.

18. Smith, E. F. 1909. Sweet corn as a means of disseminating Bacterium stewarti. (Abstr.) Science 30:223-224.

19. Smith, E. F. 1914. Stewart's disease of sweet corn (maize). Pages 89-147 in: Bacteria in Relation to Plant Diseases. Vol. 3, Vascular Diseases. Carnegie Institution of Washington, Washington, DC.

20. Steel, R. G. D., and Torrie, J. H. 1980. Principles and Procedures of Statistics: A Biometrical Approach. 2nd ed. McGraw-Hill, New York.

21. Stevens, N. E., and Wood, J. I. 1937. Recent fluctuations in plant diseases in the United States. Bot. Rev. 3:277-306.

22. Stewart, F. C. 1897. A bacterial disease of sweet corn. New York Agric. Exp. Stn. Bull. 130:422439.

23. Wallin, J. R., Loonan, D. V., and Gardner, C. A. C. 1979. Comparison of techniques for inoculating corn with Erwinia stewartii. Plant Dis. Rep. 63:390-392.

24. Wellhausen, E. J. 1937. Genetics of resistance to bacterial wilt in maize. Iowa Agric. Exp. Stn. Res. Bull. 224:69-114. 